\title{
Phenotypic and genotypic antimicrobial susceptibility pattern of Streptococcus spp. isolated from cases of clinical mastitis in dairy cattle in Poland
}

\section{E. Kaczorek, ${ }^{* 1}$ J. Małaczewska, ${ }^{*}$ R. Wójcik, ${ }^{*}$ W. Rękawek,† and A. K. Siwicki}

*Department of Microbiology and Clinical Immunology, Faculty of Veterinary Medicine, University of Warmia and Mazury in Olsztyn, Oczapowskiego 13, 10-719 Olsztyn, Poland

†Department of Internal Diseases with Clinic, Faculty of Veterinary Medicine, University of Warmia and Mazury in Olsztyn, Oczapowskiego 14, 10-957 Olsztyn, Poland

\begin{abstract}
Mastitis of dairy cattle is one of the most frequently diagnosed diseases worldwide. The main etiological agents of mastitis are bacteria of the genus Streptococcus spp., in which several antibiotic resistance mechanisms have been identified. However, detailed studies addressing this problem have not been conducted in northeastern Poland. Therefore, the aim of our study was to analyze, on phenotypic and genotypic levels, the antibiotic resistance pattern of Streptococcus spp. isolated from clinical cases of mastitis from dairy cattle in this region of Poland. The research was conducted using 135 strains of Streptococcus (Streptococcus uberis, $\mathrm{n}=53 ;$ Streptococcus dysgalactiae, $\mathrm{n}=41 ;$ Streptococcus agalactiae, $\mathrm{n}=27$; other streptococci, $\mathrm{n}=14$ ). The investigation of the antimicrobial susceptibility to 8 active substances applied in therapy in the analyzed region, as well as a selected bacteriocin (nisin), was performed using the minimum inhibitory concentration method. The presence of selected resistance genes (n $=14$ ) was determined via PCR. We also investigated the correlation between the presence of resistance genes and the antimicrobial susceptibility of the examined strains in vitro. The highest observed resistance of Streptococcus spp. was toward gentamicin, kanamycin, and tetracycline, whereas the highest susceptibility occurred toward penicillin, enrofloxacin, and marbofloxacin. Additionally, the tested bacteriocin showed high efficacy. The presence of 13 analyzed resistance genes was observed in the examined strains [gene mef(A) was not detected]. In most strains, at least one resistance
\end{abstract}

Received January 30, 2017.

Accepted April 16, 2017.

${ }^{1}$ Corresponding author: edyta.kaczorek@uwm.edu.pl gene, mainly responsible for resistance to tetracyclines $[\operatorname{tet}(\mathrm{M})$, tet $(\mathrm{K})$, tet $(\mathrm{L})]$, was observed. However, a relationship between the presence of a given resistance gene and antimicrobial susceptibility on the phenotypic level was not always observed.

Key words: Streptococcus, mastitis, resistance, nisin

\section{INTRODUCTION}

Mastitis of dairy cattle is a widespread disease. In both its clinical and subclinical form, mastitis causes enormous economic losses in the dairy industry due to decreased milk production in infected cows and costs associated with the implementation of appropriate treatment or complete elimination from herd animals with chronic mastitis (Rato et al., 2013). Healthy quarters are most often infected due to inadequate hygiene, mainly via contagious pathogens or an infection caused by environmental bacteria originating from the natural surroundings of dairy cows (Riffon et al., 2001). The bacteria of the genus Streptococcus include contagious pathogens and environmental bacteria that can cause both clinical and subclinical forms of mastitis (Heringstad et al., 2000; Bradley, 2002; Neiwert et al., 2014).

Some ways of preventing mastitis include providing balanced nutrition, reducing stress, and increasing hygiene on the farm. However, it is not always possible to avoid this disease. In this case, the most common weapon against inflammation of the udder is antimicrobial therapy (Denamiel et al., 2005). Identification of the strain responsible for the infection and determination of its antibiotic resistance profile can greatly improve the results of therapy. Unfortunately, identification is not always possible due to the cost and time required for the test (treatment is often implemented immediately; Guérin-Faublée et al., 2002). Misuse of antibiotics in nontargeted therapies or for economic purposes (growth promoters) led to an increase of and created new resistance mechanisms in bacteria. In dairy cattle 
and other farm animals produced for food, excessive use of antibiotics is associated with another risk, the creation of multiresistant foodborne pathogens, which are a hazard to human health (Rajala-Schultz et al., 2004; Pol and Ruegg, 2007; Thomas et al., 2015). To prevent this development, it is essential to monitor the trends of resistance among bacteria, in both human and veterinary medicine.

Several programs have been completed in Europe with the aim to monitor antibiotic resistance profiles [e.g., SVARM (Swedish Veterinary Antimicrobial Resistance Monitoring) 2001-2013 in Sweden, GERMAP 2008-2012 in Germany, and MARAN (Monitoring of Antimicrobial Resistance and Antibiotic Usage in Animals) 2002-2008 in the Netherlands (Thomas et al., 2015)]. Nevertheless, many countries have not undertaken such studies, which means that knowledge of the antibiotic resistance of bacteria, especially local, is limited (Denamiel et al., 2005).

Cases of multidrug resistance have forced researchers and investors to search for alternatives to antibiotics, for example, therapy with bacteriophages or bacteriocins (Gill et al., 2006; Pieterse and Todorov, 2010). For example, nisin, an antimicrobial peptide produced by Lactococcus lactis, has been approved in approximately 50 countries as an agent for food preservation. Because it shows a broad spectrum of antibacterial action against gram-positive bacteria, it is added to cheeses to prevent the growth of spores produced by Clostridium tyrobutyricum and to dairy products to protect against Listeria monocytogenes (Pieterse and Todorov, 2010). Another application of this bacteriocin is the prophylaxis of mastitis. In some countries, products containing nisin are used to disinfect the udder before and after milking. Furthermore, this bacteriocin is increasingly often considered an alternative to antibiotics. Studies conducted by Immucell Corporation (Portland, ME), in which nisin was administered to 139 cows with subclinical mastitis, have produced satisfying results. However, further research has not been performed (Pieterse and Todorov, 2010).

To the best of the authors' knowledge, few studies in Poland have focused on the mechanisms of antibiotic resistance in different pathogens, and none has focused on Streptococcus spp. isolated from cases of clinical mastitis $(\mathbf{C M})$ in dairy cattle from northeastern Poland, including their genotypic resistance. Hence, the objective of our study was to determine the profile of antibiotic resistance using the microdilution method (MIC) and molecular methods (PCR) in strains of Streptococcus spp. originating from clinical cases of mastitis in dairy cattle from northeastern Poland and to test their sensitivity to nisin.

\section{MATERIALS AND METHODS}

\section{Sample Collection}

In total, 135 streptococcal isolates from cases of clinical bovine mastitis were collected from farms in northeastern Poland from 2013 to 2015. Because the testing of epidemiologically related isolates should be avoided, only 1 isolate per dairy farm was included. Prior to milk sampling, all animals were tested using the California mastitis test. Only milk that came from quarters presenting the symptoms of infection was collected (slight thickening of the mixture; trace reaction seems to disappear with continued rotation of the paddle). After sampling, milk was kept in a container that was maintained a constant temperature of 6 to $8^{\circ} \mathrm{C}$ and was delivered to the laboratory in no more than $2 \mathrm{~h}$.

\section{Bacteriological Identification}

Milk samples were transferred with a calibrated loop (0.01 mL) on Columbia agar (Oxoid, Basingstoke, UK) and Edwards medium (Oxoid), both supplemented with $5 \%$ of defibrinated sheep blood. The plates were incubated at $37^{\circ} \mathrm{C}$ for $48 \pm 2 \mathrm{~h}$ in aerobic conditions. The grown cultures were examined microscopically after Gram staining; also the phenotypic traits were analyzed (type of hemolysis, esculin hydrolysis, production of catalase, Christie-Atkins-Munch-Petersen reaction). For further analysis, only $\mathrm{G}+$, catalase-negative cocci were selected. The final identification was performed using the commercial latex agglutination test Streptococcal Grouping Kit (Oxoid), API strep (bioMérieux, Marcy l'Etoile, France), and PCR reaction.

Antimicrobial Susceptibility Testing. Minimum inhibitory concentrations were determined using the broth microdilution method in accordance with the recommendations of the Clinical and Laboratory Standards Institute (CLSI, 2013). Antibiotics tested were enrofloxacin, erythromycin, gentamicin, lincomycin, marbofloxacin, penicillin G, and tetracycline (Sigma Aldrich, Taufkirchen, Germany) in a concentration range of 0.06 to $256 \mu \mathrm{g} / \mathrm{mL}$. Additionally, nisin (Sigma Aldrich) was tested as an alternative for antibiotics in a concentration range of 9.76 to $20,000 \mathrm{IU} / \mathrm{mL}$. All of the antimicrobials were filtered using a Millipore filter with a $0.22-\mu \mathrm{m}$ pore size (Merck Millipore, Billerica, MA). Streptococcus pneumoniae ATCC 49619 was used as a reference strain for MIC quality controls. Reference MIC values of the selected active substances are summarized in Table 1.

DNA Isolation. Bacterial DNA was extracted using an ExtractMe DNA bacteria kit (Blirt, Gdańsk, 
Poland) according to the manufacturer's protocols (http://www.dnagdansk.com/en/product,774/extractme-dna-bacteria-kit/). Eluted DNA concentrations were measured using a BioSpectrometer (Eppendorf, Hamburg, Germany) and stored at $-20^{\circ} \mathrm{C}$ for further analysis.

PCR Detection of Antimicrobial Resistance Genes and Molecular Identification of S. agalactiae, S. uberis, and $S$. dysgalactiae. The resistance genes for lincosamides $[\ln u(\mathrm{~A}), \ln u(\mathrm{D})]$, macrolides $[\operatorname{erm}(\mathrm{C}), \operatorname{erm}(\mathrm{B}), \operatorname{erm}(\mathrm{A}), \operatorname{erm}(\mathrm{TR}), \operatorname{mef}(\mathrm{A})]$, tetracyclines $[\operatorname{tet}(\mathrm{O}), \operatorname{tet}(\mathrm{L}), \operatorname{tet}(\mathrm{M}), \operatorname{tet}(\mathrm{K}), \operatorname{tet}(\mathrm{S})]$, aminoglycosides $\left(a a d-6, a p h A-3^{\prime}\right)$, and penicillin (blaZ) were searched by the PCR reaction. All genes were chosen in accordance with available literature (Table 2). For confirmation of S. agalactiae, S. uberis and S. dysgalactiae were used as species-specific primers targeting $16 \mathrm{~S}$ rRNA and $h s p$ 40. Primer sequences, product sizes, and annealing temperatures are summarized in Table 3. All primers were synthesized by Genomed S.A. (Warsaw, Poland). Amplification reactions were carried out with a HotStarTaq Plus Master Mix Kit (Qiagen, Hilden, Germany) in a nexus gradient thermocycler (Eppendorf). The $20-\mu \mathrm{L}$ reaction sample contained $10 \mu \mathrm{L}$ of HotStarTaq Plus Master Mix $2 \times, 1 \mu \mathrm{L}$ of primers (final concentration $0.4 \mu M), 2 \mu \mathrm{L}$ of CoralLoad Concentrate $10 \times$ (Qiagen), $4 \mu \mathrm{L}$ of RNase-free water, and $2 \mu \mathrm{L}$ of DNA. Cycling conditions were as follows: $95^{\circ} \mathrm{C}$ for 5 min, followed by 35 cycles of $94^{\circ} \mathrm{C}$ for $30 \mathrm{~s}$, annealing temperature for $30 \mathrm{~s}, 72^{\circ} \mathrm{C}$ for $60 \mathrm{~s}$ and final extension of $72^{\circ} \mathrm{C}$ for $10 \mathrm{~min}$. Ten microliters of PCR product was electrophoresed on $2 \%$ agarose gel in the presence of Midori Green Advance (Nippon Genetics, Düren, Germany) at $120 \mathrm{~V}$ for $60 \mathrm{~min}$. The results were read using the Quantum ST5 Gel Documentation System (Vilber, Eberhardzell, Germany). To confirm the specificity of the amplicons obtained, some PCR products of interest were randomly chosen and purified using a CleanUp kit
(A\&A Biotechnology, Gdynia, Poland) for sequencing (Genomed).

\section{RESULTS}

\section{Antimicrobial Susceptibility Testing}

Out of the 8 active substances selected, penicillin, enrofloxacin, marbofloxacin, and erythromycin were most effective against Streptococcus spp. The least effective were kanamycin, tetracycline, and gentamicin. For lincomycin, the results were difficult to interpret because cut-off values are unavailable. However, the analyzed strains showed high MIC variation against this active substance (Table 4).

The percentage of strains resistant to nisin was not determined due to the lack of cut-off values for this bacteriocin. However, even small amounts of nisin showed antimicrobial activity toward most of the analyzed strains $(\geq 9.76 \mathrm{IU} / \mathrm{mL})$. Only 3 strains (2 strains of $S$. dysgalactiae and 1 strain of $S$. uberis) had higher MIC values, greater than $312.5 \mathrm{IU} / \mathrm{mL}$ (Table 5).

\section{PCR Detection of Antimicrobial Resistance Genes}

Among the antibiotic resistance genes we analyzed, the most common were associated with resistance to tetracyclines: tet $(\mathrm{M})$ (86 positive strains, $64 \%)$, tet $(\mathrm{L})$ $(51,38 \%)$, tet $(\mathrm{K})(41,30 \%)$, and $\operatorname{tet}(\mathrm{O})(30,22 \%)$. Other frequently occurring genes were $\ln u(\mathrm{D})(25,19 \%)$ and emr(B) $(23,17 \%)$, which are responsible for resistance to lincosamides and macrolides, respectively. The gene mef(A), which encodes resistance to macrolides, was not detected among the analyzed strains. The other screened genes appeared sporadically (Table 6).

Most of the analyzed strains contained at least one of the antibiotic resistance genes. Among the Streptococcus spp. classified as others $(\mathrm{n}=14)$, all strains contained

Table 1. Reference MIC values of the selected active substances

\begin{tabular}{lcccl}
\hline & \multicolumn{3}{c}{$\begin{array}{c}\text { MIC interpretive criterion } \\
(\mu \mathrm{g} / \mathrm{mL})\end{array}$} & \\
\cline { 2 - 3 } Antimicrobial & $\mathrm{S}$ & $\mathrm{I}$ & $\mathrm{R}$ & Reference \\
\hline Enrofloxacin & $\leq 0.5$ & 1 & $\geq 2$ & CLSI VET01S ED3:2015 (CLSI, 2015) \\
Erythromycin & $\leq 0.25$ & 0.5 & $\geq 1$ & CLSI VET01S ED3:2015 (humans; CLSI, 2015) \\
Gentamicin & $\leq 4$ & 8 & $\geq 16$ & CLSI (M31-A3) 2008 (CLSI, 2008) \\
Kanamycin & $\leq 16$ & 32 & $\geq 64$ & CLSI (M31-A3) 2008 (CLSI, 2008) \\
Lincomycin & $\mathrm{ND}$ & $\mathrm{ND}$ & $\mathrm{ND}$ & No available data in veterinary and human CLSI documents \\
Marbofloxacin & $\leq 1$ & 2 & $\geq 4$ & CLSI VET01S ED3:2015 (CLSI, 2015) \\
Penicillin & $\leq 0.12$ & $0.25-2$ & $\geq 4$ & CLSI VET01S ED3:2015 (humans; CLSI, 2015) \\
Streptococcus agalactiae & $\leq 0.12$ & - & - & CLSI VET01S ED3:2015 (humans; CLSI, 2015) \\
Tetracycline & $\leq 4$ & 8 & $\geq 16$ & CLSI VET01S ED3:2015 (humans; CLSI, 2015) \\
\hline S & & &
\end{tabular}

${ }^{1} \mathrm{~S}=$ susceptible; $\mathrm{I}=$ intermediate; $\mathrm{R}=$ resistant; $\mathrm{ND}=$ no available data. 
at least one of the 14 analyzed genes. One strain of $S$. uberis and one strain of $S$. dysgalactiae simultaneously contained 6 and 7 of the genes, respectively (Table 7).

\section{Antimicrobial Susceptibility Testing and PCR Detection of Antimicrobial Resistance Genes for Tetracycline, Erythromycin, and Penicillin}

Most tetracycline-resistant strains had at least one of the genes we analyzed. Only $S$. dysgalactiae and other Streptococcus spp. had strains in which, despite the in vitro resistance, none of the analyzed genes with resistance to tetracyclines were detected. Moreover, some of the phenotypically susceptible strains were found to contain some of the analyzed antimicrobial resistance genes.

In the case of erythromycin, a macrolide antibiotic, the prevalent strains were those susceptible under in vitro conditions, in which the presence of the targeted antibiotic resistance genes was not detected. As in the case of tetracycline, some susceptible strains were discovered that had antibiotic resistance genes. Despite the confirmed resistance under in vitro conditions, some strains were not verified to contain any of the analyzed genes.

Regarding penicillin, most strains we analyzed showed phenotypic susceptibility despite the sporadic presence of the gene blaZ. However, blaZ was undetected in strains with higher MIC values (Table 8).

\section{DISCUSSION}

Antibiotic therapy is one of the principal choices in the treatment of mastitis in dairy cattle. Consequently, pathogens and their antibiotic resistance have long been the focus of numerous research teams around the world as potential infection agents or as a source of genes linked to drug resistance in people and animals (Rajala-Schultz et al., 2004; Pol and Ruegg, 2007; Thomas et al., 2015).

Table 2. Selected genes with references

\begin{tabular}{|c|c|c|c|}
\hline Item & Gene & Previously confirmed & Reference \\
\hline \multirow[t]{2}{*}{ Lincosamides } & $\ln u(\mathrm{~A})$ & $\begin{array}{l}\text { Enterococcus faecalis } \\
\text { Enterococcus hirae } \\
\text { Enterococcus avium } \\
\text { Enterococcus spp. }\end{array}$ & Jackson et al., 2010 \\
\hline & $\ln u(\mathrm{D})$ & Streptococcus uberis & Petinaki et al., 2008 \\
\hline \multirow[t]{16}{*}{ Macrolides } & $\operatorname{erm}(\mathrm{C})$ & $\begin{array}{l}\text { Streptococcus agalactiae } \\
\text { Streptococcus dysgalactiae }\end{array}$ & Entorf et al., 2016 \\
\hline & $\operatorname{erm}(\mathrm{B})$ & S. agalactiae & Lu et al., 2016 \\
\hline & & S. dysgalactiae & Entorf et al., 2016 \\
\hline & & S. uberis & Haenni et al., 2011 \\
\hline & & Streptococcus viridans group & Gajić et al., 2014 \\
\hline & & $\begin{array}{l}\text { Streptococcus pneumoniae } \\
\text { Streptococcus pyogenes }\end{array}$ & Rodriguez-Avial et al., 2003 \\
\hline & $\operatorname{erm}(\mathrm{A})$ & S. agalactiae & Rato et al., 2013 \\
\hline & & S. pyogenes & Gajić et al., 2014 \\
\hline & & S. viridans group & Rodriguez-Avial et al., 2003 \\
\hline & $\operatorname{erm}(\mathrm{TR})$ & S. agalactiae & Lu et al., 2016 \\
\hline & $\operatorname{mef}(\mathrm{A})$ & S. agalactiae & Entorf et al., 2016 \\
\hline & & S. dysgalactiae & Gajić et al., 2014 \\
\hline & & S. uberis & Rodriguez-Avial et al., 2003 \\
\hline & & S. pneumoniae & \\
\hline & & S. pyogenes & \\
\hline & & S. viridans group & \\
\hline \multirow[t]{9}{*}{ Tetracyclines } & tet $(\mathrm{O})$ & S. agalactiae & Rato et al., 2013 \\
\hline & & $S$ viridans group & Rodriguez-Avial et al., 2003 \\
\hline & tet $(\mathrm{K})$ & S. agalactiae & Rato et al., 2013 \\
\hline & $\operatorname{tet}(\mathrm{M})$ & S. agalactiae & Rato et al., 2013 \\
\hline & & S. viridans group & Rodriguez-Avial et al., 2003 \\
\hline & $\operatorname{tet}(\mathrm{L})$ & S. agalactiae & Lu et al., 2016 \\
\hline & & S. viridans group & Rodriguez-Avial et al., 2003 \\
\hline & $\operatorname{tet}(\mathrm{S})$ & E. faecalis & Charpentier et al., 1994 \\
\hline & & S. dysgalactiae & Liu et al., 2008 \\
\hline \multirow[t]{4}{*}{ Aminoglycosides } & aad- 6 & Streptococcus bovis & Leclercq et al., 2005 \\
\hline & & S. agalactiae & Zeng et al., 2006 \\
\hline & aphA-3' & S. bovis & Leclercq et al., 2005 \\
\hline & & S. agalactiae & Zeng et al., 2006 \\
\hline Penicillins & blaZ & Streptococcus spp. & Ruegg et al., 2015 \\
\hline
\end{tabular}




\section{Antimicrobial Susceptibility Testing}

The tools applied to monitor these issues include both phenotypic and genotypic methods, which provide the opportunity to observe new antibiotic resistance mechanisms developing in a given geographical area or among particular groups of bacteria. Unfortunately, whereas in human medicine both MIC values and inhibition zones have been established for most pathogens, in veterinary medicine, much of this information does not exist. Hence, cut-off values are often adopted from other animal species, other groups of bacteria, or human medicine standards (Thomas et al., 2015). Under these circumstances, it is difficult to accurately determine the actual level of antibiotic resistance among veterinary pathogens. Studies that monitor the phenotypic (especially MIC values) and genotypic profile of antibiotic resistance of pathogens isolated from cases of various diseases and in different parts of the world based on pharmacokinetic data will enable researchers to unify or to establish a system to interpret the results of susceptibility testing. Hence, in our research, we focused on bacteria from the genus Streptococcus isolated from dairy cattle reared in northeastern Poland. To the best of our knowledge, no such detailed study of the phenotypic and genotypic profile of antibiotic resistance of Streptococcus spp. in dairy cattle with mastitis has been performed in this part of Poland.

For the antimicrobial susceptibility testing, we selected the active substances that are most commonly administered in the analyzed region of Poland. Of the 8 antibiotics, the most effective were penicillin, marbofloxacin, and enrofloxacin, whereas the least effective were kanamycin, gentamicin, and tetracycline. These

Table 3. Primer sets used for the identification of Streptococcus uberis, Streptococcus agalactiae, Streptococcus dysgalactiae, and antimicrobial resistance determinants in Streptococcus spp. isolated from clinical mastitis samples from the northeast region of Poland

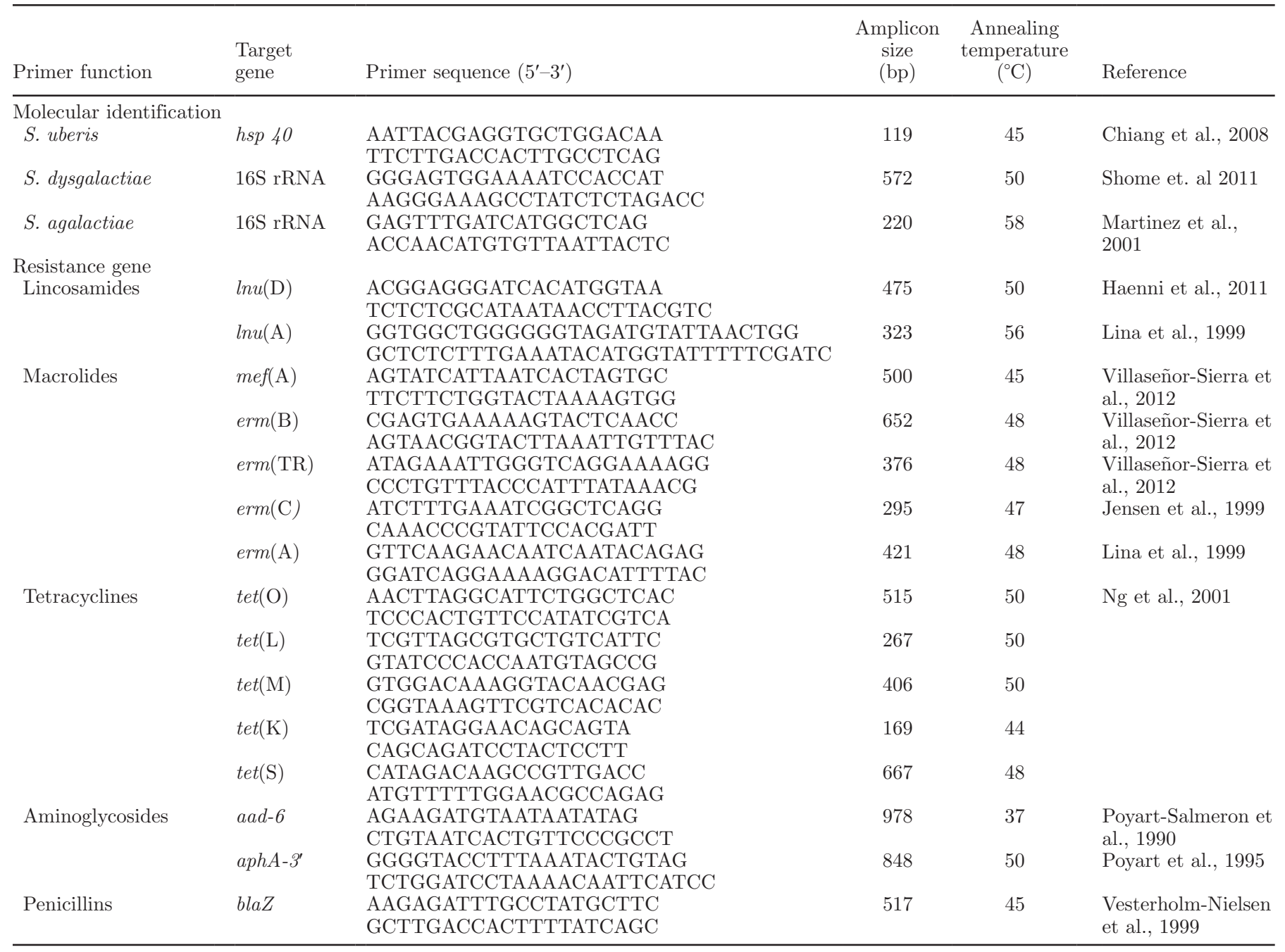


Table 4. Minimum inhibitory concentration distribution for Streptococcus uberis $(\mathrm{n}=53)$, Streptococcus agalactiae $(\mathrm{n}=27)$, Streptococcus dysgalactiae $(\mathrm{n}=41)$, and other Streptococcus $\mathrm{spp} .(\mathrm{n}=14)$ from clinical mastitis samples in dairy cattle ${ }^{1}$

\begin{tabular}{|c|c|c|c|c|c|c|c|c|c|c|c|c|c|c|}
\hline \multirow{2}{*}{$\begin{array}{l}\text { Antimicrobial } \\
\text { and species }\end{array}$} & \multicolumn{13}{|c|}{$\mathrm{MIC}(\mu \mathrm{g} / \mathrm{mL})$} & \multirow[b]{2}{*}{$\mathrm{R} \%$} \\
\hline & $\leq 0.06$ & 0.125 & 0.250 & 0.50 & 1 & 2 & 4 & 8 & 16 & 32 & 64 & 128 & $\geq 256$ & \\
\hline S. uberis & & & 4 & 40 & 9 & & & & & & & & & 0 \\
\hline S. agalactiae & & & 1 & 11 & 15 & & & & & & & & & 0 \\
\hline S. dysgalactiae & & & 1 & 20 & 18 & 2 & & & & & & & & 5 \\
\hline Other & & & 2 & 4 & 6 & 1 & 1 & & & & & & & 14 \\
\hline S. agalactiae & 24 & & 1 & & 2 & & & & & & & & & 7 \\
\hline S. dysgalactiae & 27 & 4 & 1 & & & 3 & & & & 1 & 3 & 1 & 1 & 22 \\
\hline Other & 8 & 3 & 1 & & 1 & & & & & & 1 & & & 14 \\
\hline \multicolumn{15}{|l|}{ Gentamicin } \\
\hline S. uberis & & & & & & 2 & & & 7 & 21 & 19 & 4 & & 96 \\
\hline S. agalactiae & & & & & & & & 1 & 2 & 13 & 10 & 1 & & 100 \\
\hline S. dysgalactiae & & & & & 1 & 2 & 10 & 11 & 6 & 7 & 4 & & & 68 \\
\hline Other & & & & & & & & & 6 & & 6 & 1 & 1 & 57 \\
\hline \multicolumn{15}{|l|}{ Lincomycin } \\
\hline S. uberis & 21 & 5 & 1 & & 1 & 9 & 2 & & & 1 & 1 & 6 & 6 & $\mathrm{ND}$ \\
\hline S. agalactiae & 5 & 12 & 2 & 1 & & & & 5 & & & 1 & & 1 & $\mathrm{ND}$ \\
\hline S. dysgalactiae & 4 & 14 & 8 & 1 & & 4 & 3 & 1 & 3 & 2 & & 1 & & $\mathrm{ND}$ \\
\hline Other & & & 1 & & 1 & 4 & & & 2 & 2 & & 2 & 2 & $\mathrm{ND}$ \\
\hline \multicolumn{15}{|l|}{ Marbofloxacin } \\
\hline S. uberis & & & & 4 & 43 & 5 & & & & & 1 & & & 2 \\
\hline S. agalactiae & & & & 1 & 18 & 7 & 1 & & & & & & & 4 \\
\hline S. dysgalactiae & & & & 6 & 26 & 7 & & & 1 & & 1 & & & 5 \\
\hline Other & & & & 1 & 5 & 5 & 2 & 1 & & 1 & & & & 29 \\
\hline \multicolumn{15}{|l|}{ Penicillin } \\
\hline S. uberis & 49 & 2 & & & 1 & 1 & & & & & & & & 0 \\
\hline
\end{tabular}

${ }^{1} \mathrm{R} \%$ = percentage of resistant strains; $\mathrm{ND}=$ no data about cut-off values for this active substance.

results are in partial agreement with those reported by other researchers. In studies conducted in western Portugal and China, bacteria of the genus Streptococcus showed the least susceptibility toward gentamicin and tetracycline (Gao et al., 2012; Rato et al., 2013). Worse efficacy of tetracycline has been reported worldwide and can be attributed to its excessive use in the past, both in nontargeted therapies (mostly diseases of the

Table 5. Minimum inhibitory concentration distribution of nisin for Streptococcus uberis $(\mathrm{n}=53)$, Streptococcus agalactiae $(\mathrm{n}=27)$, Streptococcus dysgalactiae $(\mathrm{n}=41)$, and other Streptococcus spp. $(\mathrm{n}=14)$ from clinical mastitis samples from the northeast region of Poland

\begin{tabular}{|c|c|c|c|c|c|c|c|c|c|c|c|c|}
\hline \multirow[b]{2}{*}{ Item } & \multicolumn{12}{|c|}{ Nisin $(\mathrm{IU} / \mathrm{mL})$} \\
\hline & $\leq 9.76$ & 19.5 & 39.1 & 78.1 & 156.3 & 312.5 & 625 & 1,250 & 2,500 & 5,000 & 10,000 & 20,000 \\
\hline S. agalactiae & 15 & 4 & 5 & & 3 & & & & & & & \\
\hline S. dysgalactiae & 18 & 1 & 8 & 10 & 2 & 1 & 1 & & & & & \\
\hline Other & 6 & 2 & 1 & 4 & 1 & & & & & & & \\
\hline
\end{tabular}




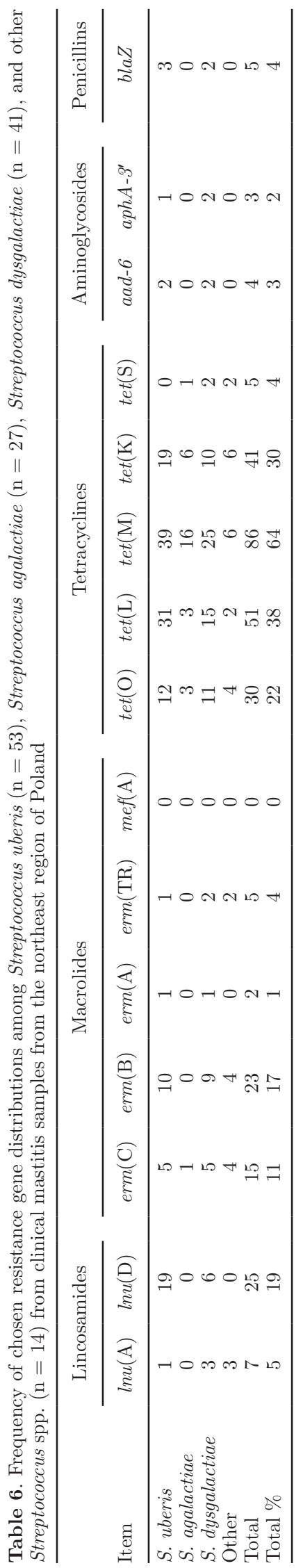

respiratory but also the digestive systems) and as a growth promoter, for example, on fish farms (Speer et al., 1992; Gajda et al., 2012; Rato et al., 2013). For aminoglycosides, the situation is more complicated. Bacteria of the genus Streptococcus show a naturally lower susceptibility to this group of antibiotics, which is a consequence of the limited permeation of these antibiotics through the cell wall. To enhance their activity, aminoglycosides in human medicine are usually administered in combination with $\beta$-lactams (Taber et al., 1987). In light of this information, the increased resistance of bacteria to this group of antibiotics verified in our experiment is unsurprising. Previous reports in the literature, however, demonstrated lowered susceptibility of Streptococcus spp. only toward streptomycin (Jayarao and Oliver, 1992). Additional investigations have revealed that bacteria of the genus Streptococcus have become resistant to gentamicin and kanamycin. As in the case of tetracycline, this development was likely stimulated by the excessive/unreasonable application of this antibiotic in nontargeted therapies, including cases of udder inflammation, both in cattle and in small ruminants (Lollai et al., 2008; Rato et al., 2013).

The Streptococcus spp. strains isolated in our study included those with higher MIC toward penicillin, which is commonly claimed to be an active substance with the highest in vitro efficacy against this group of bacteria (Haenni et al., 2010; Ruegg et al., 2015). Resistance to penicillin is so rare that whenever such strains are identified, CLSI recommends repeating both drug resistance tests and strain identification (McDougall et al., 2014). Nonetheless, the occurrence of such strains was observed in Europe in a study conducted by Thomas et al. (2015), where approximately $30 \%$ of the analyzed strains were classified as intermediate susceptible to this active substance. Strains of $S$. dysgalactiae and $S$. agalactiae with increased MIC values toward penicillin have also been isolated in Argentina (Denamiel et al., 2005). The isolation of such strains in the region we analyzed could be due to the occurrence of a mutation of penicillin-binding proteins, resulting in decreased affinity for this drug. This phenomenon has been confirmed in $S$. pneumoniae, S. agalactiae, S. suis, and S. uberis, but our study did not perform detailed assays in this direction (Haenni et al., 2010; McDougall et al., 2014). We concentrated on determining the presence of blaZ gene, encoding $\beta$-lactamase, which is responsible for enzymatic hydrolysis of the ring of $\beta$-lactam antibiotics. The presence of this gene has been verified in Staphylococcus aureus, Enterococcus faecalis, and Streptococcus spp. causing mastitis in cattle in the United States (Murray et al., 1986; Lowy, 2003; Ruegg et al., 2015). Despite the confirmed presence of this gene among the strains analyzed in our 
Table 7. Frequency of the occurrence [no. (\%)] of individual genes and multiple genes for Streptococcus uberis $(\mathrm{n}=53)$, Streptococcus agalactiae $(\mathrm{n}=27)$, Streptococcus dysgalactiae $(\mathrm{n}=41)$, and other Streptococcus species $(\mathrm{n}=14)$ isolated from clinical mastitis samples from the northeast region of Poland

\begin{tabular}{|c|c|c|c|c|c|c|c|c|}
\hline Item & No genes & 1 Gene & 2 Genes & 3 Genes & 4 Genes & 5 Genes & 6 Genes & 7 Genes \\
\hline S. agalactiae & $6(22)$ & $14(52)$ & $5(19)$ & $2(7)$ & & & & \\
\hline S. dysgalactiae & $8(20)$ & $9(22)$ & $7(17)$ & $4(10)$ & $7(17)$ & $5(12)$ & & $1(2)$ \\
\hline
\end{tabular}

research, we did not observe a correlation between this gene and increased MIC values.

The strains analyzed in our study demonstrated a relatively high susceptibility to erythromycin (approximately $80 \%$ of the analyzed strains). Our results were surprising compared with data reported in Germany and France, where Streptococcus strains have been observed to be more resistant to macrolides (GuérinFaublée et al., 2002; Minst et al., 2012).

The minimal resistance of the Streptococcus spp. strains isolated in our research toward marbofloxacin and enrofloxacin, 2 quinolone antibiotics, is in agreement with the results achieved by other researchers (Kroemer et al., 2012; Ruegg et al., 2015).

\section{Detection of Antimicrobial Resistance Genes}

In addition to the phenotypic method applied to evaluate the final antibiotic resistance under in vitro conditions, genotypic determinations were performed for the selected genes encoding different resistance mechanisms. The 5 genes chosen for the group of tetracyclines were those that most often appeared in bacteria of the genus Streptococcus spp., which encoded resistance to this group of antibiotics via the protection of ribosomes $[$ tet $(\mathrm{M})$, tet $(\mathrm{O})$, tet $(\mathrm{S})]$, as well as through the efflux pump [tet(L) and tet(K)] (Poyart et al., 2003; Dogan et al., 2005; Gao et al., 2012). The presence of all the selected genes was confirmed among the analyzed strains, which supports our earlier hypothesis that this group of antibiotics had been excessively used in the past in the analyzed region. Of the analyzed genes, the following occurred the most frequently: tet $(\mathrm{M}), \operatorname{tet}(\mathrm{L})$, and $\operatorname{tet}(\mathrm{K})$. The frequent presence of the gene tet $(\mathrm{M})$ among the analyzed strains is surprising because, as Dogan et al. (2005) states, until recently, this gene had been associated with strains of Streptococcus agalactiae isolated from humans. In contrast, studies conducted in China and in the United States have confirmed the frequent presence of this gene among bovine isolates, which can be explained by horizontal gene transfer within the same genus (Gao et al., 2012; Ruegg et al., 2015). For macrolides, 4 genes of the erm class were selected for analysis $[\operatorname{erm}(\mathrm{A}), \operatorname{erm}(\mathrm{B}), \operatorname{erm}(\mathrm{C})$, erm

Table 8. Comparison of phenotypic and genotypic antimicrobial resistance for selected active substances in Streptococcus uberis $(\mathrm{n}=53)$, Streptococcus dysgalactiae $(\mathrm{n}=41)$, Streptococcus agalactiae $(\mathrm{n}=27)$, and other Streptococcus species $(\mathrm{n}=14)$ isolated from clinical mastitis samples from the northeast region of Poland ${ }^{1}$

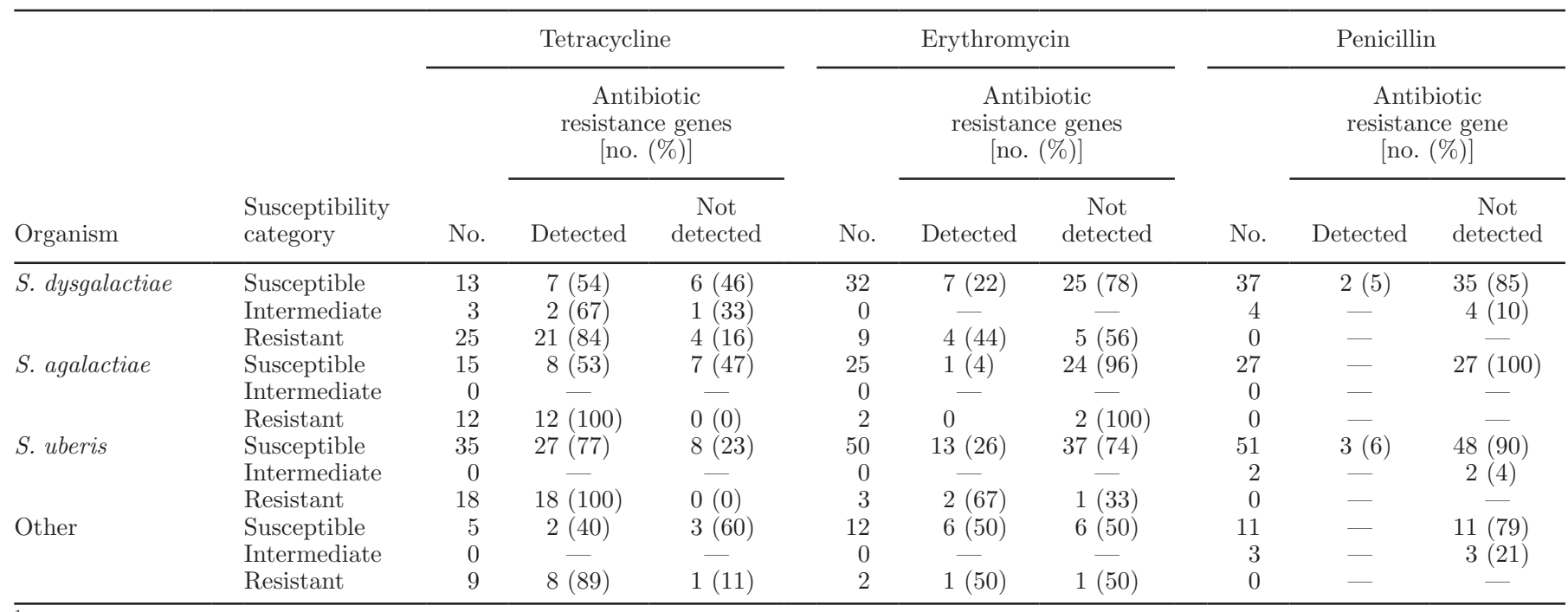

${ }^{1}$ Detected $=$ any resistance gene detected for this active substance. 
(TR)], all encoding methylase, which reduces the binding of antibiotics to the target site, both in this group and lincosamides or type B streptogramins (Denamiel et al., 2005). In our study, the gene $\operatorname{erm}(\mathrm{B})$ was dominant, and our results are similar to those obtained by other authors (Loch et al., 2005; Gao et al., 2012; Rato et al., 2013). According to Loch et al. (2005), this result can be explained by the location of this gene on transposons, which is transferred to different bacteria, including bacteria of the genus Streptococcus, via horizontal gene transfer. The strains analyzed in our experiment were confirmed to contain the genes $\mathrm{erm}(\mathrm{TR})$ and $\mathrm{erm}(\mathrm{C})$, which previously tended to remain undetected in bovine isolates (Dogan et al., 2005). Our finding can be explained by the fact that there are preparations registered for use in Poland that contain macrolides and lincosamides and are used in mammary gland therapy in cattle. When misused, they can create ideal conditions for the transfer of genes of this class among bacteria. Additionally, we examined the presence of the gene mef(A), encoding the efflux pump responsible for resistance to 14 - and 15-membered macrolides. The presence of this gene has previously been confirmed in human isolates of $S$. pneumoniae (Szczypa et al., 2013). Nevertheless, this gene was not detected among the strains we analyzed, and this result is consistent with previous reports (Loch et al., 2005; Schmitt-Van de Leemput and Zadoks, 2007; Rato et al., 2013).

Bacteria of the genus Streptococcus demonstrate cross-resistance to macrolides-lincosamides-type B streptogramins, mostly arising from the presence of the erm genes. However, in addition to this group of genes, Streptococcus spp. bacteria also contain genes associated with specific resistance to lincosamides, which are popular antibiotics used in mastitis treatment in dairy cattle (lincomycin, pirlimycin). The genes responsible for resistance to this group of antibiotics are the $\ln u$ class genes, which encode nucleotidyltransferases, resulting in enzymatic inactivation of a drug. This mechanism was first described for Enterococcus faecium, and it was originally thought that this type of resistance appears in this single species. However, it was later observed in other bacteria, for example, $S$. agalactiae and S. uberis (Petinaki et al., 2008; Arana et al., 2014). In the geographic region we analyzed, the presence of genes from this class $[\ln u(\mathrm{~A})$ and $\ln u(\mathrm{D})]$ has also been confirmed, which raises serious concerns. The presence of these genes was observed only in pathogens classified as environmental bacteria, which may indicate that genes from this group are widespread in northeastern Poland.

The last group of genes we analyzed consisted of genes associated with resistance to aminoglycosides (i.e., aad-6 and aphA-3'), which cause enzymatic in- activation of these antibiotics. The presence of these genes was determined in single strains of $S$. uberis and $S$. dysgalactiae. The results can be seen as optimistic compared with data reported from China and France, where the presence of these genes has been observed in a larger percentage of analyzed strains. However, our study included only the 2 most frequently occurring genes. Moreover, we did not examine strains of Enterococcus spp., in which these genes occur much more frequently. Therefore, our results should be considered with caution, and future investigations should include determination of these genes in the group of bacteria mentioned above (Poyart et al., 2003; Gao et al., 2012; Jaimee and Halami, 2016).

\section{Comparison of Phenotypic Resistance and Occurrence of Resistance Genes for 3 Active Substances}

We compared the results from in vitro studies of antibiotic resistance to the presence of genes for 3 active substances (tetracyclines, erythromycin, and penicillin) in individual strains of bacteria. Our decision was dictated by the high frequency of occurrence of genes associated with antibiotic resistance toward the 2 former active substances. Penicillin was included because of the presence of blaZ and the elevated MIC for this substance, which is an extremely rare event. For all 3 active substances, a lack of correlation was noted between the presence of resistance genes and the degree of susceptibility of bacteria under in vitro conditions. According to Gao et al. (2012), this finding can be explained in 2 ways. The first assumes that phenotypic resistance in some cases can be associated with point mutations in genes rather than the presence of these genes. Another possibility is that there is no expression of a given gene due to an excessive distance to the promotor or its absence at the front of a coding sequence. Another phenomenon we observed was the formation of phenotypic resistance in the absence of the analyzed genes. The same hypothesis was posited by Ruegg et al. (2015), citing resistance to macrolides-lincosamidestype B streptogramins, where the presence of as many as 21 genes responsible for this type of cross-resistance was confirmed. Another possible reason is the lack of data in the CLSI guidelines for veterinary strains, which necessitates the borrowing of missing values from data on other animal species or norms established for human pathogens (McDougall et al., 2014). Nevertheless, the fact that antibiotic resistance genes were found in the region we examined is worrying as it indicates the possibility of horizontal gene transfer. Even if a bacterium possessing a resistance gene cannot use it, it can transfer the gene to another pathogen, which 
facilitates the spread of resistance in a given area (Bennett, 2008). In our study, a considerable number of the analyzed strains contained at least one gene associated with antimicrobial resistance to the analyzed active substances. Therefore, the above genes can spread over the analyzed geographical area, as described above. Nonetheless, no research concerning these genes in this group of bacteria with respect to antibiotic resistance has been conducted in northeastern Poland; therefore, the above hypothesis is difficult to validate.

\section{Efficiency of Nisin}

Antibiotics make it possible to cope with numerous infectious diseases. However, their excessive use, both for medical purposes and in animal rearing, has created many antibiotic resistance mechanisms, including multiresistant bacteria, resulting in the current search for solutions that are an alternative to antibiotics. We tested nisin, a bacteriocin with bactericidal activity toward gram-positive bacteria. Low concentrations of nisin $(\geq 9.76 \mathrm{IU} / \mathrm{mL})$ showed bactericidal activity toward most of the analyzed strains. Similar results were achieved by Severina et al. (1998), who proved the efficacy of this bacteriocin toward penicillin-resistant strains of $S$. pneumoniae. Even when the bacteriocin alone is unable to eradicate a certain gram-positive bacterium, its addition to a selected antibiotic greatly enhances its efficacy. Tong et al. (2014) added $200 \mathrm{IU} /$ $\mathrm{mL}$ of nisin to active substances, which decreased the MIC values for reference strains of E. faecalis. This effect is attributed to the ability of nisin to form pores, which improves the penetration of the antibiotic into bacterial cells. Although our study analyzed the effect of nisin alone on isolated strains of Streptococcus spp., the results are promising and raise hope that this bacteriocin will be useful in the treatment of mastitis caused by bacteria of the genus Streptococcus in cattle.

\section{CONCLUSIONS}

There are some worrying developments in the studied region, on both the genotypic and phenotypic level, in bacteria of the genus Streptococcus spp. isolated from clinical cases of mastitis in dairy cows. The high resistance of the analyzed strains toward tetracycline and aminoglycosides suggests that greater care should be taken when these substances are used in veterinary practice. Moreover, the presence of a large number of genes linked to antibiotic resistance in the analyzed strains of bacteria demands further research to monitor this phenomenon, analyze the occurrence of point mutations in the verified genes, and assess the risk of horizontal transfer of resistance genes. The results raise concerns regarding the growing presence of antibiotic resistance in streptococci, but they give us hope that it might be possible to implement an alternative to antibiotics (i.e., nisin) in medical practice across the country. However, additional, more detailed studies in this field are required.

\section{ACKNOWLEDGMENTS}

Publication was supported by KNOW (Leading National Research Centre) Scientific Consortium "Healthy Animal-Safe Food," decision of the Ministry of Science and Higher Education No. 05-1/KNOW2/2015 (Poland).

\section{REFERENCES}

Arana, D. M., B. Rojo-Bezares, C. Torres, and J. I. Alós. 2014. First clinical isolate in Europe of clindamycin resistant group B Streptococcus mediated by the $\operatorname{lnu}(\mathrm{B})$ gene. Rev. Esp. Quimioter. 27:106109.

Bennett, P. M. 2008. Plasmid encoded antibiotic resistance: Acquisition and transfer of antibiotic resistance genes in bacteria. Br. J. Pharmacol. 153:S347-S357.

Bradley, A. 2002. Bovine mastitis: An evolving disease. Vet. J. 164:116-128.

Charpentier, E., G. Gerbaud, and P. Courvalin. 1994. Presence of the Listeria tetracycline resistance gene tet $(\mathrm{S})$ in Enterococcus faecalis. Antimicrob. Agents Chemother. 38:2330-2335.

Chiang, Y. C., W. Y. Pai, C. Y. Chen, and H. Y. Tsen. 2008. Use of primers based on the heat shock protein genes hsp 70 , hsp 40, and hsp 10, for the detection of bovine mastitis pathogens Streptococcus agalactiae, Streptococcus uberis and Streptococcus bovis. Mol. Cell. Probes 22:262-266.

CLSI (Clinical and Laboratory Standards Institute). 2008. Performance standards for antimicrobial disk and dilution susceptibility tests for bacteria isolated from animals; approved standard, 3rd Ed. CLSI document M31-A3. CLSI, Wayne, PA.

CLSI (Clinical and Laboratory Standards Institute). 2013. Performance standards for antimicrobial disk and dilution susceptibility tests for bacteria isolated from animals, 4th ed. CLSI, Wayne, PA.

CLSI (Clinical and Laboratory Standards Institute). 2015. Performance standards for antimicrobial disk and dilution susceptibility tests for bacteria isolated from animals, CLSI Document VET01S. 3rd ed. CLSI, Wayne, PA.

Denamiel, G., P. Llorente, M. Carabella, M. Rebuelto, and E. Gentilini. 2005. Anti-microbial susceptibility of Streptococcus sp. isolated from bovine mastitis in Argentina. J. Vet. Med. B Infect. Dis. Vet. Public Health 52:125-128.

Dogan, B., Y. H. Schukken, C. Santisteban, and K. J. Boor. 2005. Distribution of serotypes and antimicrobial resistance genes among Streptococcus agalactiae isolates from bovine and human hosts. J. Clin. Microbiol. 43:5899-5906.

Entorf, M., A. T. Feßler, H. Kaspar, K. Kadlec, T. Peters, and S. Schwarz. 2016. Comparative erythromycin and tylosin susceptibility testing of streptococci from bovine mastitis. Vet. Microbiol. 194:36-42.

Gajda, A., A. Posyniak, J. Żmudzki, and H. Różańska. 2012. Occurrence of tetracyclines in tissues and food of animal origin: causes and consequences. Med. Weter. 68:650-655.

Gajić, I., V. Mijać, N. Opavski, M. Stanojević, I. Lazarević, A. Śmitran, M. Hadnadev, and L. Ranin. 2014. Distribution of macrolide-resistant genes among isolates of macrolideresistant Streptococcus pyogenes and Streptococcus pneumoniae in Serbia. Arch. Biol. Sci. 66:93-98. 
Gao, J., F. Q. Yu, L. P. Luo, J. Z. He, R. G. Hou, H. Q. Zhang, S. M. Li, J. L. Su, and B. Han. 2012. Antibiotic resistance of Streptococcus agalactiae from cows with mastitis. Vet. J. 194:423-424.

Gill, J. J., J. C. Pacan, M. E. Carson, K. E. Leslie, M. W. Griffiths, and P. M. Sabour. 2006. Efficacy and pharmacokinetics of bacteriophage therapy in treatment of subclinical Staphylococcus aureus mastitis in lactating dairy cattle. Antimicrob. Agents Chemother. 50:2912-2918.

Guérin-Faublée, V., F. Tardy, C. Bouveron, and G. Carret. 2002. Antimicrobial susceptibility of Streptococcus species isolated from clinical mastitis in dairy cows. Int. J. Antimicrob. Agents 19:219-226.

Haenni, M., L. Galofaro, M. Ythier, M. Giddey, P. Majcherczyk, P. Moreillon, and J. Y. Madec. 2010. Penicillin-binding protein gene alterations in Streptococcus uberis isolates presenting decreased susceptibility to penicillin. Antimicrob. Agents Chemother. $54: 1140-1145$

Haenni, M., E. Saras, S. Chaussière, M. Treilles, and J. Y. Madec. 2011. ermB-mediated erythromycin resistance in Streptococcus uberis from bovine mastitis. Vet. J. 189:356-358.

Heringstad, B., G. Klemetsdal, and J. Ruane. 2000. Selection for mastitis resistance in dairy cattle: A review with focus on the situation in the Nordic countries. Livest. Prod. Sci. 64:95-106.

Jackson, C. R., P. J. Fedorka-Cray, J. A. Davis, J. B. Barrett, J. H. Brousse, J. Gustafson, and M. Kucher. 2010. Mechanisms of antimicrobial resistance and genetic relatedness among enterococci isolated from dogs and cats in the United States. J. Appl. Microbiol. 108:2171-2179.

Jaimee, G., and P. M. Halami. 2016. High level aminoglycoside resistance in Enterococcus, Pediococcus and Lactobacillus species from farm animals and commercial meat products. Ann. Microbiol. $66: 101-110$.

Jayarao, B. M., and S. P. Oliver. 1992. Aminoglycoside-resistant Streptococcus and Enterococcus species isolated from bovine mammary secretions. J. Dairy Sci. 75:991-997.

Jensen, L. B., N. Frimodt-Møller, and F. M. Aarestrup. 1999. Presence of erm gene classes in gram-positive bacteria of animal and human origin in Denmark. FEMS Microbiol. Lett. 170:151-158.

Kroemer, S., D. Galland, V. Guérin-Faublée, H. Giboin, and F. Woehrlé-Fontaine. 2012. Survey of marbofloxacin susceptibility of bacteria isolated from cattle with respiratory disease and mastitis in Europe. Vet. Rec. 170:53. https://doi.org/10.1136/vr.100246.

Leclercq, R., C. Huet, M. Picherot, P. Trieu-Cuot, and C. Poyart. 2005. Genetic basis of antibiotic resistance in clinical isolates of Streptococcus gallolyticus (Streptococcus bovis). Antimicrob. Agents Chemother. 49:1646-1648.

Lina, G., A. Quaglia, M. E. Reverdy, R. Leclercq, F. Vandenesch, and J. Etienne. 1999. Distribution of genes encoding resistance to macrolides, lincosamides, and streptogramins among Staphylococci. Antimicrob. Agents Chemother. 43:1062-1066.

Liu, L. C., J. C. Tsai, P. R. Hsueh, S. P. Tseng, W. C. Hung, H. J. Chen, and L. J. Teng. 2008. Identification of tet(S) gene area in tetracycline-resistant Streptococcus dysgalactiae ssp. equisimilis clinical isolates. J. Antimicrob. Chemother. 61:453-455.

Loch, I. M., K. Glenn, and R. N. Zadoks. 2005. Macrolide and lincosamide resistance genes of environmental streptococci from bovine milk. Vet. Microbiol. 111:133-138.

Lollai, S. A., M. Ziccheddu, C. D. Mauro, D. Manunta, A. Nudda and G. Guido Leori. 2008. Profile and evolution of antimicrobial resistance of ovine mastitis pathogens (1995-2004). Small Rumin. Res. 74:249-254.

Lowy, F. D. 2003. Antimicrobial resistance: The example of Staphylococcus aureus. J. Clin. Invest. 111:1265-1273.

Lu, B., X. Chen, J. Wang, D. Wang, J. Zeng, Y. Li, D. Li, F. Zhu, Y. Cui, and L. Huang. 2016. Molecular characteristics and antimicrobial resistance in invasive and noninvasive Group B Streptococcus between 2008 and 2015 in China. Diagn. Microbiol. Infect. Dis. $86: 351-357$.

Martinez, G., J. Harel, and M. Gottschalk. 2001. Specific detection by PCR of Streptococcus agalactiae in milk. Can. J. Vet. Res. 65:68-72.
McDougall, S., H. Hussein, and K. Petrovski. 2014. Antimicrobial resistance in Staphylococcus aureus, Streptococcus uberis and Streptococcus dysgalactiae from dairy cows with mastitis. N. Z. Vet. J. 62:68-76.

Minst, K., E. Märtlbauer, T. Miller, and C. Meyer. 2012. Streptococcus species isolated from mastitis milk samples in Germany and their resistance to antimicrobial agents. J. Dairy Sci. 95:6957-6962.

Murray, B. E., D. A. Church, A. Wanger, K. Zscheck, M. E. Levison, M. J. Ingerman, E. Abrutyn, and B. Mederski-Samoraj. 1986. Comparison of two beta-lactamase-producing strains of Streptococcus faecalis. Antimicrob. Agents Chemother. 30:861-864.

Neiwert, O., O. Holst, and K. A. Duda. 2014. Structural investigation of rhamnose-rich polysaccharides from Streptococcus dysgalactiae bovine mastitis isolate. Carbohydr. Res. 389:192-195.

Ng, L. K., I. Martin, M. Alfa, and M. Mulvey. 2001. Multiplex PCR for the detection of tetracycline resistant genes. Mol. Cell. Probes 15:209-215.

Petinaki, E., V. Guérin-Faublée, V. Pichereau, C. Villers, A. Achard, B. Malbruny, and R. Leclercq. 2008. Lincomycin Resistance Gene $\operatorname{lnu}(\mathrm{D})$ in Streptococcus uberis. Antimicrob. Agents Chemother. $52: 626-630$.

Pieterse, R., and S. D. Todorov. 2010. Bacteriocins - Exploring alternatives to antibiotics in mastitis treatment. Braz. J. Microbiol. $41: 542-562$.

Pol, M., and P. L. Ruegg. 2007. Treatment practices and quantification of antimicrobial drug usage in conventional and organic dairy farms in Wisconsin. J. Dairy Sci. 90:249-261.

Poyart, C., J. Celli, and P. Trieu-Cuot. 1995. Conjugative transposition of Tn916-related elements from Enterococcus faecalis to Escherichia coli and Pseudomonas fluorescens. Antimicrob. Agents Chemother. 39:500-506.

Poyart, C., L. Jardy, G. Quesne, P. Berche, and P. Trieu-Cuot. 2003. Genetic basis of antibiotic resistance in Streptococcus agalactiae strains isolated in a French hospital. Antimicrob. Agents Chemother. 47:794-797.

Poyart-Salmeron, C., C. Carlier, P. Trieu-Cuot, A. L. Courtieu, and P. Courvalin. 1990. Transferable plasmid-mediated antibiotic resistance in Listeria monocytogenes. Lancet 335:1422-1426.

Rajala-Schultz, P. J., K. L. Smith, J. S. Hogan, and B. C. Love. 2004. Antimicrobial susceptibility of mastitis pathogens from first lactation and older cows. Vet. Microbiol. 102:33-42.

Rato, M. G., R. Bexiga, C. Florindo, L. M. Cavaco, C. L. Vilela, and I. Santos-Sanches. 2013. Antimicrobial resistance and molecular epidemiology of streptococci from bovine mastitis. Vet. Microbiol. 161:286-294.

Riffon, R., K. Sayasith, H. Khalil, P. Dubreuil, M. Drolet, and J. Lagace. 2001. Development of a rapid and sensitive test for identification of major pathogens in bovine mastitis by PCR. J. Clin. Microbiol. 39:2584-2589.

Rodriguez-Avial, I., C. Rodriguez-Avial, E. Culebras, and J. J. Picazo. 2003. Distribution of tetracycline resistance genes tet(M), tet(O), tet $(\mathrm{L})$ and tet $(\mathrm{K})$ in blood isolates of viridans group streptococci harbouring erm(B) and mef(A) genes. Susceptibility to quinupristin/dalfopristin and linezolid. Int. J. Antimicrob. Agents 21:536541.

Ruegg, P. L., L. Oliveira, W. Jin, and O. Okwumabua. 2015. Phenotypic antimicrobial susceptibility and occurrence of selected resistance genes in gram-positive mastitis pathogens isolated from Wisconsin dairy cows. J. Dairy Sci. 98:4521-4534.

Schmitt-Van de Leemput, E., and R. N. Zadoks. 2007. Genotypic and phenotypic detection of macrolide and lincosamide resistance in Streptococcus uberis. J. Dairy Sci. 90:5089-5096.

Severina, E., A. Severin, and A. Tomasz. 1998. Antibacterial efficacy of nisin against multidrug-resistant Gram-positive pathogens. J. Antimicrob. Chemother. 41:341-347.

Shome, B. R., S. Das Mitra, M. Bhuvana, N. Krithiga, D. Velu, R. Shome, S. Isloor, S. B. Barbuddhe, and H. Rahman. 2011. Multiplex PCR assay for species identification of bovine mastitis pathogens. J. Appl. Microbiol. 111:1349-1356. 
Speer, B. S., N. B. Shoemaker, and A. A. Salyers. 1992. Bacterial resistance to tetracycline: Mechanisms, transfer, and clinical significance. Clin. Microbiol. Rev. 5:387-399.

Szczypa, K., J. Wilemska, W. Hryniewicz, and I. Sitkiewicz. 2013. Epidemiology of Streptococcus pyogenes infections, clonal structure population and antibiotic resistance. Postepy Mikrobiol. 52:223232

Taber, H. W., J. P. Muller, P. F. Miller, and A. S. Arrow. 1987. Bacterial uptake of aminoglycoside antibiotics. Microbiol. Rev. 51:439 457.

Thomas, V., A. de Jong, H. Moyaert, S. Simjee, F. El Garch, I. Morrissey, H. Marion, and M. Vallé. 2015. Antimicrobial susceptibility monitoring of mastitis pathogens isolated from acute cases of clinical mastitis in dairy cows across Europe: VetPath results. Int. J. Antimicrob. Agents 46:13-20.

Tong, Z., Y. Zhang, J. Ling, J. Ma, L. Huang, and L. Zhang. 2014. An in vitro study on the effects of Nisin on the antibacterial activities of 18 antibiotics against Enterococcus faecalis. PLoS One 9:e89209. https://doi.org/10.1371/journal.pone.0089209.

Vesterholm-Nielsen, M., M. Ø. Larsen, J. E. Olsen, and F. M. Aarestrup. 1999. Occurrence of the blaZ gene in penicillin resistant Staphylococcus aureus isolated from bovine mastitis in Denmark. Acta Vet. Scand. 40:279-286.

Villaseñor-Sierra, A., E. Katahira, A. N. Jaramillo-Valdivia, L. Barajas-García Mde, A. Bryant, R. Morfín-Otero, F. Márquez-Díaz, J. C. Tinoco, J. Sánchez-Corona, and D. L. Stevens. 2012. Phenotypes and genotypes of erythromycin-resistant Streptococcus pyogenes strains isolated from invasive and non-invasive infections from Mexico and the USA during 1999-2010. Int. J. Infect. Dis. 16:e178-e181. https://doi.org/10.1016/j.ijid.2011.11.005.

Zeng, X., F. Kong, H. Wang, A. Darbar, and G. L. Gilbert. 2006. Simultaneous detection of nine antibiotic resistance-related genes in Streptococcus agalactiae using multiplex PCR and reverse line blot hybridization assay. Antimicrob. Agents Chemother. 50:204-209. 